\title{
A CLASSIFICATION AND DESCRIPTION OF THE SHRUBLAND VEGETATION ON Platberg, Eastern Free State, South Africa
}

Authors:

Robert F. Brand ${ }^{1}$

Pieter J. du Preez ${ }^{2}$

Leslie R. Brown ${ }^{1}$

\section{Affiliations:}

${ }^{1}$ Applied Behavioural

Ecology and Ecosystem

Research Unit,

Department of

Environmental Sciences,

University of South

Africa, South Africa

${ }^{2}$ Department of Plant

Sciences, University of

the Free State, South

Africa

Correspondence to:

Leslie R. Brown

e-mail:

lrbrown@unisa.ac.za

Postal address:

Department of

Environmental Sciences,

Unisa (Florida campus),

P/Bag X6, Florida, 1710,

South Africa

Keywords:

Drakensberg Alpine

Centre (DAC); Braun-

Blanquet; TWINSPAN;

floristic links; inselberg

\section{Dates:}

Received: 12 Mar. 2009

Accepted: 17 Sept. 2009

Published: 22 Oct. 2009

How to cite this article: Brand, R.F., Du Preez,

P.J. \& Brown, L.R.,

2009, 'A classification and description of the shrubland vegetation on Platberg, Eastern

Free State, South Africa', Koedoe 51(1), Art. \#696,

11 pages. DOI: $10.4102 /$ koedoe.v51i1.696

This article is available at:

http://www.koedoe.co.za

(C) 2009. The Authors. Licensee: OpenJournals Publishing. This work is licensed under the Creative Commons Attribution License.

\section{ABSTRACT}

The natural environment is constantly under threat from human-related activities. Platberg, overlooking the town of Harrismith in the Free State, is an inselberg that presents a refuge for indigenous plants and animals. The natural vegetation of the area is threatened by various farming and grazing practices, as well as by commercial development. In order to obtain baseline data and to obtain an improved understanding of the long-term ecological processes, the vegetation of Platberg was investigated to establish Afroalpine floristic links to the Drakensberg, as well as for the management of natural resources. From a Two-Way Indicator-Species Analysis (TWINSPAN) classification, refined by Braun-Blanquet methods, four major plant communities were identified, which were subdivided into fynbos, wetland, woody/shrub and grassland. A classification and description of the shrubland is presented in this article.

The analysis showed the shrubland divided into 20 different plant communities, which are grouped into eight major communities, 13 sub-communities and eight variants. A total of 450 species was recorded from 109 relevés. A total of 24 endemic, or near-endemic, and Red Data species belonging to the Drakensberg Alpine Centre (DAC) was collected, with 22 alien (introduced) species also being recorded. Numerous floristic links with the DAC, the Cape Floristic Region and the Grassland Bioregions to the north and west were found.

Conservation implications: The floristic composition and community analysis proves Platberg to be an important centre for plant diversity, with high species richness, a variety of habitats, and complex ecosystems. This description of the woodland communities can be used to assist with the setting of criteria for the management and protection of inselbergs in the province.

\section{INTRODUCTION}

The natural environment is continually under threat from development, pollution, alien species invasions, and other human-related actions (Millennium Ecosystem Assessment 2005). The increasing pressures imposed by such actions threaten to lead to a loss of plant and animal species, which could lead to the degradation of an area. The prevention of large-scale loss of biodiversity is a daunting challenge facing the world today (Huntley 1991). In order to conserve our natural resources, ecosystems must be studied to allow for the compilation of an inventory of our natural resources. Platberg, in the Eastern Free State, overlooking the town of Harrismith, is an inselberg that serves as a refuge for indigenous plants and animals.

Plant communities occurring on inselbergs form unique phytosociological associations (Parmentier et al. 2006; Porembski \& Brown 1995; Sarthou \& Villiers 1998). However, inselberg plant associations also feature numerous species that occur in the vegetation matrix surrounding the inselbergs (Mutke et al. 2001), in which the inselberg flora is embedded.

The unique, high-altitude conditions found above $2000 \mathrm{~m}$ in the Drakensberg region of South Africa lead to high levels of endemism in plants and animals (Carbutt \& Edwards 2006; Hillard \& Burtt 1987; Mucina \& Rutherford 2006; Van Wyk \& Smith 2001). Such high levels of endemism are due to the compression of climatic life zones within a relatively small space, which makes mountains hotspots for biological diversity (Körner 2003). Mountains may be regarded as analogous with an archipelago of islands in an 'ocean' of low-level vegetation types which act as an isolation factor (MacArthur \& Wilson 2001; Taylor 1996). This, in turn, precludes plant species with less mobile seed dispersal mechanisms from propagating over wide ranges, and allows for high levels of endemism to develop (Hilliard \& Burtt 1987; Taylor 1996). High levels of endemism mean that a large proportion of the available gene pool is unique to a particular site, and inselbergs and mountains, therefore, have an important role to play in the maintenance of genetic diversity (Mucina \& Rutherford 2006; Taylor 1996).

Prior to the current study, no extensive vegetation surveys had been undertaken on Platberg, with only limited opportunistic floristic collections being undertaken in the mid-1960s by Mrs M.L. Jacobs, with some 50 relevés being sampled by Professor H.J.T. Venter of the University of the Free State (UFS) between 1975 and 1977. (The vouchers from both collectors are housed at the Geo Potts Herbarium, UFS.) Due to the proposed commercial development by the Platberg Conservancy, as well as the aims of the Maloti-Drakensberg Transfrontier Project, it was considered necessary to undertake a more detailed and extensive ecological survey aimed at describing and classifying the vegetation of the Platberg.

\section{Study area}

Location

Platberg is the largest inselberg situated in the area approximately $60 \mathrm{~km}$ north of the main massif of the Maluti/Drakensberg range (Geological Survey maps; 1:50 000 scale). It also has the highest peak in the area, Mtabazwe (2 394.5 m; Survey Beacon 44), as well as the largest inselberg capped by igneous rock (Du Toit 1956; King 1963; McCarthy \& Rubidge 2005; Norman \& Whitfield 1998). It forms a distinctive 


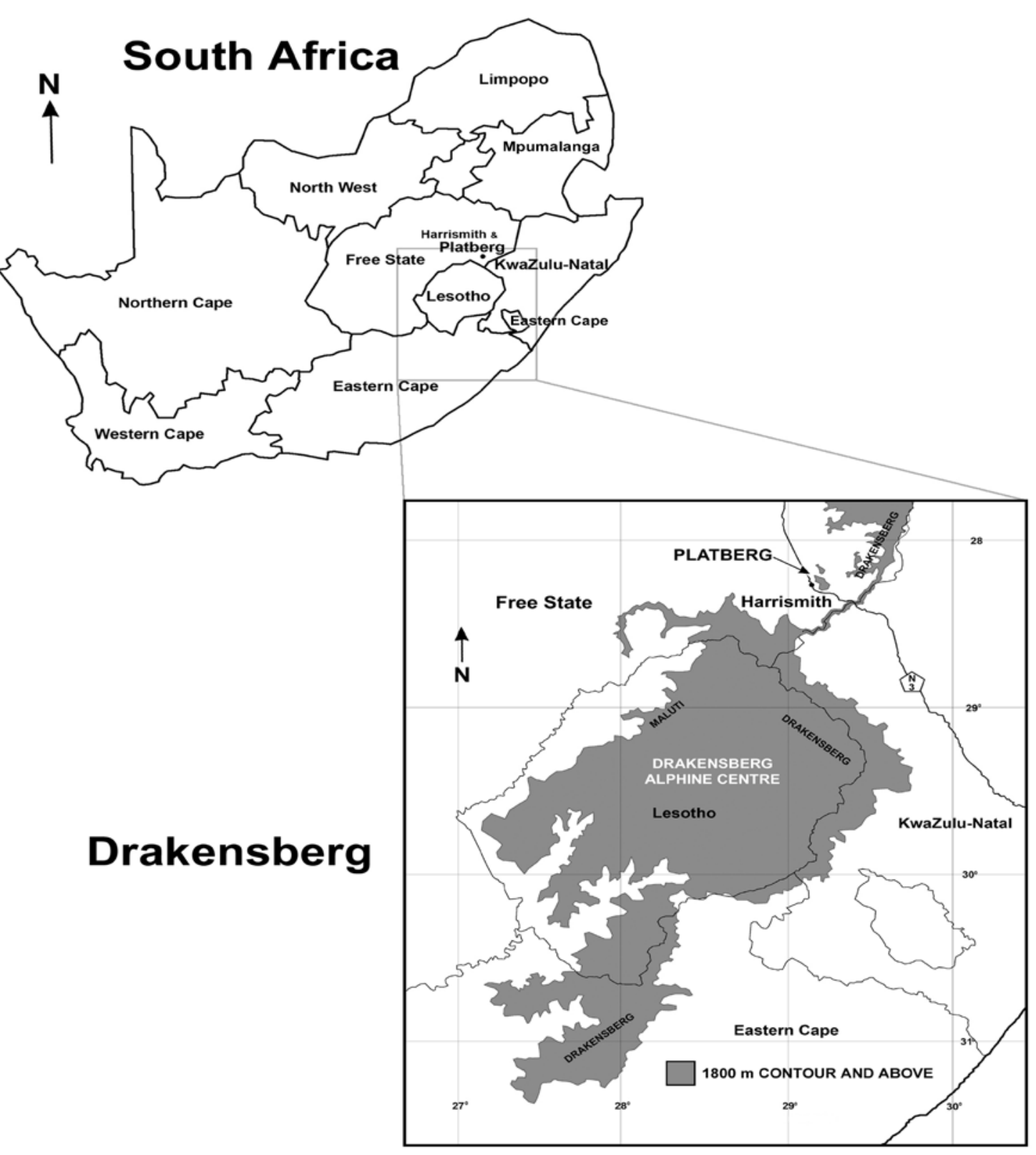

FIGURE 1

Location of the study area

flat-topped, L-shaped plateau with clear-cut contact between the Stormberg volcanism and the Cave Sandstone of the Clarens Formation.

Platberg is located at latitude S $29^{\circ}-10^{\prime}$ and longitude E $28^{\circ}-16^{\prime}$ on the N3 highway between Johannesburg and Durban (see Figure 1). The altitude ranges from $1900 \mathrm{~m}$ to $2394 \mathrm{~m}$, with the surface area of the study site being approximately 3000 ha. The slopes are steep, with numerous vegetated gullies and boulder scree slopes below the vertical cliffs, which are $20 \mathrm{~m}$ to $45 \mathrm{~m}$ high. Waterfalls cascade down the southern cliffs after rain.

\section{Vegetation}

Platberg falls within the Grassland Biome (or the Drakensberg Grassland Bioregion; Mucina \& Rutherford 2006), with generally short to tall sour grasses (Acocks 1988; Low \& Rebelo 1998). It also has elements of Fynbos and False Karoo (Acocks) or Succulent Karoo (Low \& Rebelo 1998), as well as elements of Temperate and Transitional Forests, and specifically of the Highland Sourveld (Acocks) biomes.
The vegetation description presented by Mucina \& Rutherford (2006) shows the study area located within the Northern Drakensberg Highland Grassland (Gm5) and Lesotho Highland Basalt Grassland (Gd8), both within the Drakensberg Grassland Bioregion.

\section{Geology}

Platberg consists of layers of the Karoo Supergroup which stratigraphically lie immediately below the volcanics of the Drakensberg Formation, which is the youngest (Jurassic, 65 million years) unit of the Stormberg Group (Brand, Du Preez \& Brown 2008).

\section{Topography and soils}

Figure 2 shows a terrain-form sketch of the study area. The steep slopes are composed of shale and mostly sandstone of the Clarens Formation intersected by dolerite dykes, resulting in benches, deep ravines and terraces. Numerous sandstone and basalt boulders form scree and boulder slopes, resulting 


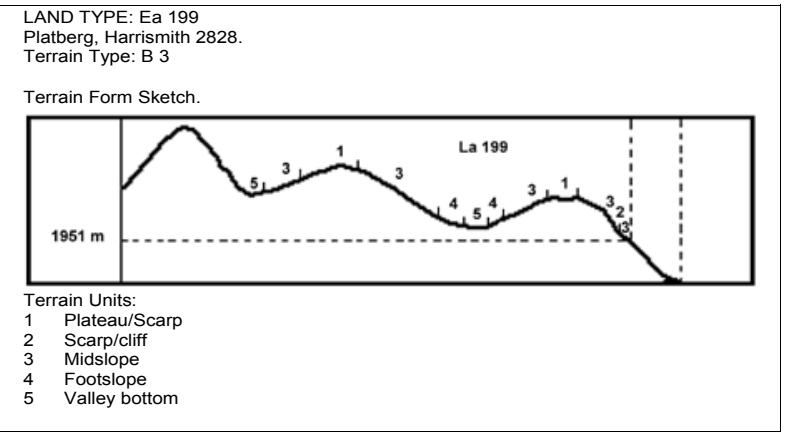

FIGURE 2
Landscape sketch showing the principal terrain units (Land Type Survey Staff 1991)

in miscellaneous soil forms, characteristic of $\mathrm{Ib}$ land type, specifically Mispah (Ms), and Glenrosa (Gs), soil forms (Du Preez 1991; MacVicar et al. 1991; Mucina \& Rutherford 2006). There are affinities with Fa land types, with the undulating rocky landscape being dominated by shallow Ms and Gs soil forms (Land Type Survey Staff 1991; Smit et al. 1993).

The summit plateau is composed of igneous rock, specifically basalt and dolerite, established from thin section studies of Platberg rock samples (Brand et al. 2008). The soils are generally shallow (20-200 mm), with the deepest being $<500 \mathrm{~mm}$. Derived from basalt and dolerite, they are shown to have even proportions of course sand, fine sand, clay, silt and moderate to high organic matter content. The main land type is Ea comprising clay vertic, melanic or red diagnostic horizons (MacVicar et al. 1991; Mucina \& Rutherford 2006; Smit, Bredenkamp \& Van Rooyen 1993), with a clay content of $8 \%$ to $60 \%$, dependant on soil series (Land Type Survey Staff 1991).

\section{Climate}

The average annual precipitation for the study area ranges between 800 and $1200 \mathrm{~mm}$ per annum, with the mean daily maximum temperatures fluctuating between $22^{\circ} \mathrm{C}$ to $24^{\circ} \mathrm{C}$ for January, and the lowest daily mean temperatures for June and July of $-2^{\circ} \mathrm{C}$ to $0^{\circ} \mathrm{C}$. The daily mean relative humidity for the most humid month, March, varies between $68 \%$ and $72 \%$, with the daily minimum relative humidity for July and August varying between $32 \%$ and 38\% (Mucina \& Rutherford 2006; Schulze 1997; South African Weather Services 2007; Van Zinderen Bakker 1973).

Snow, which is recorded at the top of Platberg during most winters, can remain on the ground for up to two weeks (D. Weaver, G. Weaver, S. Falanga \& C. Gobbles pers. comm. 2008). Water in south-facing gullies may stay frozen for several weeks at a time (Mucina \& Rutherford 2006; Van Zinderen Bakker 1973). Possible heave soils are present on Mtabazwe (the highest point on Platberg; personal observation c.p.w. Hilliard \& Burtt 1987) and might be a significant factor in controlling vegetation at high altitudes (Hilliard \& Burtt 1987; Mucina \& Rutherford 2006).

\section{METHODS}

A total of 109 sample plots was placed within the shrubland communities of Platberg. The aim of the study was to sample above the $1900 \mathrm{~m}$ contour, in order to work within the limits set by Killick (1963, 1978a, 1978b), who regarded the region in the Drakensberg above the $1800 \mathrm{~m}$ as a distinct floristic region, namely the Afroalpine Region. Plot sizes were fixed at $100 \mathrm{~m}^{2}$ (Du Preez 1991, 1992; Du Preez \& Bredenkamp 1991a; Malan 1998; Westhoff \& Van der Maarel 1980; Whitaker 1980,). In all sample plots, each species was recorded, with all woody plants being counted and the cover abundance being estimated using the Braun-Blanquet cover scale (Mueller-Dombois \& Ellenberg 1974; Whitaker 1980).
Fieldwork was undertaken in February/March 2005, and again at the start of the summer growing season from October to December 2005, continuing until the end of March 2006. Final follow-up field work was conducted during January 2007.

Over 1500 floristic collections were made and identified at the UFS Herbarium and the National Herbarium, Pretoria. All taxa names conform to Germishuizen \& Meyer (2003). In the structural assessment of the woody vegetation, all woody species were divided into three groups based on height, namely shrubs (> $0-2 \mathrm{~m})$, trees (>2-6 m) and tall trees (>6 m) (Brand 2007).

Habitat, as well as floristic data, was processed using TURBOVEG (Hennekens 1996a). A first approximation was undertaken using the two-way indicator-species analysis classification (TWINSPAN) algorithm (Hill 1979). The result was refined with the aid of the MEGATAB table editing program (Hennekens 1996b), in order to obtain a phytosociological table indicating the classification of the vegetation types, with their species composition. Further refinement of the classification was undertaken through the application of Braun-Blanquet procedures (Barbour, Burk \& Pitts 1987; Kent \& Coker 1992).

Numerous phytosociological studies have shown this to be a suitable numerical classification system to use (for example Barrett et al. 2006; Bredenkamp \& Brown 2003; Du Preez 1991; Du Preez \& Bredenkamp 1991a; Grobler, Bredenkamp \& Brown 2002; Malan 1998; Pond et al. 2002). MEGATAB (Hennekens 1996b) was used to generate a phytosociological table, with further refinements being undertaken in Excel (Kent \& Coker 1992).

Erosion was estimated using the three-scale numerical system, where $1=$ no erosion, $2=$ moderate and $3=$ high (Brand 2007). Slope was estimated using the following scale in degrees: Flat $-0^{\circ}$ to $3^{\circ}$; Gradual $-3^{\circ}$ to $8^{\circ}$; Moderate $-8^{\circ}$ to $16^{\circ}$; Steep $16^{\circ}$ to $26^{\circ}$; Very Steep $-26^{\circ}$ to $45^{\circ}$; Greater than $-45^{\circ}$. Soil depths were measured with a probe graded for $5 \mathrm{~cm}$ intervals to a maximum of $30 \mathrm{~cm}$.

\section{Vegetation classification \\ RESULTS}

A total of 450 species was recorded for the woody shrub vegetation. The floristic analysis identified 20 plant communities, which are grouped into eight major communities (see Table 1) (online appendix)

1. Themeda triandra-Watsonia lepida community

1.1 Themeda triandra-Watsonia lepida-Harpochloa falx subcommunity

1.1.1 Cyphia elata variant

1.1.2 Cliffortia ramosissima variant

1. 2 Themedatriandra-Watsonialepida-Andropogon appendiculatus sub-community

1.2.1 Helictotrichon longifolium variant

1.2.2 Lotononis lotononoides variant

1.3 Themeda triandra-Watsonia lepida-Ficinia stolonifera subcommunity

1.4 Themeda triandra-Watsonia lepida-Printzia pyrifolia subcommunity

1.5 Themeda triandra-Watsonia lepida-Tristachya leucothrix subcommunity

2. Leucosidea sericea-Hyparrhenia hirta community

3. Rhus pyroides-Pteridium aquilinum community

4. Diospyros whyteana-Euclea crispa community

4.1 Diospyros whyteana-Euclea crispa-Bowiea volubilis subcommunity

4.1.1 Maytenus undata variant

4.1.2 Bidens pilosa variant

4.2 Diospyros whyteana-Euclea crispa-Themeda triandra subcommunity 
5. Kiggelaria africana-Crassula lanceolata community

5.1 Kiggelaria africana-Crassula lanceolata-Senecio isatideus sub-community

5.2 Kiggelaria africana-Crassula lanceolata-Zehneria scabra subcommunity

6. Buddleja loricata-Rhus divaricata community

6.1 Buddleja loricata-Rhus divaricata-Gallium scabrelloides subcommunity

6.2 Buddleja loricata-Rhus divaricata-Stachys grandifolia subcommunity

6.2.1 Clutia hirsuta variant

6.2.2 Stachys grandifolia variant

7. Asparagus ramosissimus-Leucosidea sericea community

7.1 Asparagus ramosissimus-Leucosidea sericea-Fraxinus angustifolia sub-community

7.2 Asparagus ramosissimus-Leucosidea sericea-Plectranthus grallatus sub-community

8. Senecio inornatus-Thamnocalamus tessellatus community

The shrubland vegetation is found on the steep slopes; in gullies, ravines and along water courses; on the boulder scree slopes; on the cliffs at their bases, and on the rock ridges and outcrops of the summit plateau area. On the cool south and east side of Platberg, dense continuous woody stands of shrubs occur.

The general vegetation of the Shrubland Community is characterised by plants from Species Group AL (Table 1), particularly Leucosidea sericea, while species from Species Groups AA and W are also prominent locally. Buddleja salviifolia (Species Group X) is present in most communities. Stachys grandifolia (Species Group AE) has a strong, but more limited and widely scattered, presence. The climber, Clematis brachiata (Species Group AG), too, has a strong, though scattered, presence in the mountain bamboo Thamnocalamus tessellatus community.

\section{Themeda triandra-Watsonia lepida community}

The Themeda triandra-Watsonia lepida community is found on all aspects of the summit plateau and the steep footslopes. The altitude varies between 1920 and $2340 \mathrm{~m}$, with the soil being shallow $(40 \mathrm{~mm})$ to deep $(300 \mathrm{~mm})$. The summit soils are well drained and composed of degraded igneous rocks. The footslopes are composed of a mix of igneous and sandstone of the Clarens Formation of $\mathrm{Ib}$ soil type. Rock cover varies from $5 \%$ to $45 \%$, with erosion and levels of trampling varying from zero to moderate or high. For small trees, the total canopy cover varies between $5 \%$ and $30 \%$, while tall trees had a cover ranging between $5 \%$ and $10 \%$. The total canopy cover varied from 5\% to $80 \%$ for shrubs. Herbaceous cover varied between $5 \%$ and $50 \%$.

Species belonging to Species Group $M$ are characteristic of the community and include the perennial bunch grasses Themeda triandra, Tristachya leucothrix, Eragrostis racemosa; the shrubs Indigofera hedyantha and Athrixia phylicoides; the bulb Watsonia lepida; the forbs Ajuga ophyrdis, Aster bakeranus, Anthspermum herbaceum, Euphorbia striata, Helichrysum dasycephalum Helichrysum nudifolium, Heliophila rigidiuscula, Lotononis procumbens, Rhynchosia totta, Senecio glaberrimus, Schistostephium crataegifolium, Senecio rhomboideus, Vernonia natalensis, and the grass root parasite Thesium pallidum.

The community is dominated by the shrub Leucosidea sericea (Species Group AL); the perennial grasses Themeda triandra, Tristachya leucothrix; and the bulb Watsonia lepida (Species Group $\mathrm{M})$. Prominent species include the grasses Cymbopogon dieterlenii (Species Group T), and Eragrostis curvula (Species Group Y), and the forb Senecio inornatus (Species Group AL). An average of 32.22 species per $100 \mathrm{~m}^{2}$ was recorded for the community under review.

\subsection{Themeda triandra-Watsonia lepida-Harpochloa falx sub-community}

The small geophyte sub-community is located on all aspects of Platberg, including on the flat, rocky summit outcrops and on the very steep slopes $>45^{\circ}$. Soils are derived from either igneous summit rocks or sedimentary Cave Sandstone. Soils are shallow, being between 10 and $60 \mathrm{~mm}$, or $>300 \mathrm{~mm}$ deep, and seasonally damp. Moderate surface erosion was recorded, with no evidence of trampling. Rock cover was found to vary between $20 \%$ and $50 \%$.

The sub-community is characterised by the presence of the small geophyte Albuca humilis and the forb Wahlenbergia cuspidata (Species Group C). Prominent species include the grass Harpochloa falx (Species Group I), and Eragrostis curvula (Species Group Y); the sedge Ficinia gracillis (Species Group I); and the geophyte Watsonia lepida (Species Group M). The average number of species recorded per $100 \mathrm{~m}^{2}$ was 40.5 .

Two variants of the sub-community are recognised:

1.1.1 Cyphia elata variant: The variant is characterised by species from Species Group A, being dominated by the shrub Buddleja salviifolia (Species Group X) and the climber Clematis brachiata (Species Group AG).

1.1.2 Cliffortia ramosissima variant: The variant is characterised by species from Species Group B. The vegetation is dominated by the fynbos shrub Cliffortia ramosissima (Species Group B); the grasses Heteropogon contortus (Species Group H), Themeda triandra, and Tristachya leucothrix (Species Group M); and the geophyte Watsonia lepida (Species Group M)

\subsection{Themeda triandra-Watsonia lepida-Andropogon} appendiculatus sub-community

The Themeda triandra-Watsonia lepida-Andropogon appendiculatus sub-community is located on the cool southern aspects, on terrain with gradients ranging from $8^{\circ}$ to $>45^{\circ}$. It has two altitudinal locations, a lower one at 1976 to $2150 \mathrm{~m}$ on the sandstones of the Clarens Formation, and a higher one at $2287 \mathrm{~m}$, on the rolling summit plateau. Rock cover varies between $5 \%$ and $35 \%$. Soils are $300 \mathrm{~mm}$ deep and seasonally moist, with no signs of erosion or trampling. The canopy cover, which varies between $5 \%$ and $40 \%$, is provided by shrubs.

The sub-community, which is characterised by species from Species Group E (Table 1), includes the tall bunch grass Andropogon appendiculatus and the forbs Monsonia attenuata and Silene bellidioides.

The vegetation is dominated by two bunch grasses, Andropogon appendiculatus (Species Group E) and Themeda triandra (Species Group M), and the shrub Leucosidea sericea (Species Group AL). Grasses and sedges that are prominent include Aristida monticola and Carex zuluensis, (Species Group K). Other species also present include the bulb Watsonia lepida (Species Group M); the alien bramble Rubus ludwigii (Species Group T); the forb Senecio inornatus; and the geophyte Agapanthus campanulatus (Species Group AL). An average of 24.6 species was recorded per 100 $\mathrm{m}^{2}$.

1.2.1 Helictotrichon longifolium variant: The variant is characterised by the absence of species from Species Groups C, D and F. The vegetation is dominated by the shrub Leucosidea sericea (Species Group AL), and the bunch grasses Andropogon appendiculatus (Species Group E) and Themeda triandra (Species Group M).

1.2.2 Lotononis lotononoides variant: The variant is characterised by species from Species Group D. Species that dominate this variant include the shrubs Lotononis lotononoides (Species Group D) and Leucosidea sericea (Species Group AL); the grass Themeda triandra; and the bulb Watsonia lepida (Species Group M).

\subsection{Themeda triandra-Watsonia lepida-Ficinia stolonifera sub-community}

The sub-community is located at 1925 to $2218 \mathrm{~m}$ altitudes, on 
the southern and south-western aspects with moderately steep to very steep slopes. Rock size varies from gravel $<10 \mathrm{~mm}$ to boulders $>200 \mathrm{~mm}$. The geology is the Cave Sandstone of the Clarens Formation, plateau basalt and dolerite dykes. Rock exposure varies from $0 \%$ to $25 \%$. Soil erosion and trampling are zero to moderate. The soils range from shallow (60 to $180 \mathrm{~mm}$ ) to deep $>300 \mathrm{~mm}$. Several relevés had a canopy cover of $15 \%$ to $50 \%$ for shrubs.

The sub-community, which is characterised by species from Species Group F, includes the sedge Ficinia stolonifera and the forbs Haplocarpha scaposa, Linum thunbergii and Sebaea exigua.

Plants that dominate the sub-community include the shrub Leucosidea sericea (Species Group AL), and the grasses Heteropogon contortus (Species Group H); Themeda triandra (Species Group $\mathrm{M})$, and Eragrostis curvula (Species Group Y). Other important species include the shrub Rhus discolor (Species Group P); the grasses Harpochloa falx (Species Group I), Aristida monticola, Helictotrichon longifolium (Species Group K), Tristachya leucothrix (Species Group M), Cymbopogon dieterlenii (Species Group T), and Eragrostis curvula (Species Group Y); and the forb Senecio inornatus (Species Group AL), which is found in moist locations. The average number of species recorded per $100 \mathrm{~m}^{2}$ was 41.2 . The species composition of tall and short perennial bunch grasses indicates the grassland on rocky terrain in dynamic transition with colonisation by low woody species (Mucina \& Rutherford 2006).

\subsection{Themeda triandra-Watsonia lepida-Printzia pyrifolia sub-community}

The small sub-community is located on the southern and southwestern aspects, between $1940 \mathrm{~m}$ and $2057 \mathrm{~m}$ on the very steep slopes below the basalt cliffs on rocky ridges and outcrops of sandstone and dolerite. Rock size is $>500 \mathrm{~mm}$, with rock cover ranging between $10 \%$ and $40 \%$. No trampling or erosion was noted. Soils are shallow (60 to $1200 \mathrm{~mm}$ ) and > $300 \mathrm{~mm}$ deep. Canopy cover for shrubs varies between $15 \%$ and $60 \%$.

Species from Species Group J, namely the shrubs Printzia pyrifolia and Indigofera hewittii and the perennial bunch grass Helictotrichon turgidulum are diagnostic for this variant.

The small tree Leucosidea sericea and the shrubs Myrsine africana (Species Group AL) Printzia pyrifolia (Species Group J), and Calpurnia sericea (Species Group T) dominate the vegetation. A well-developed grass layer includes Aristida monticola (Species Group K), Themeda triandra (Species Group M), Cymbopogon dieterlenii (Species Group T), and Ehrharta erecta (Species Group $\mathrm{AL}$ ). In this small community, an average of 37.3 species per 100 $\mathrm{m}^{2}$ was recorded.

\subsection{Themeda triandra-Watsonia lepida-Tristachya leucothrix sub-community}

The sub-community is located at altitudes ranging between 2027 $\mathrm{m}$ and $2047 \mathrm{~m}$, on various aspects, with gradual to steep slopes on the mid-slopes below the basalt cliffs. Rock size is $>200 \mathrm{~mm}$. Rock exposure ranges from $0 \%$ to $35 \%$. Levels of trampling and erosion are zero to moderate. Soils are well drained and $40 \mathrm{~mm}$ to $200 \mathrm{~mm}$ deep. The sub-community has shrubs, which provide canopy cover between $5 \%$ and $50 \%$.

The sub-community is characterised by species from Species Group L, including the forb Gerbera piloselloides, the tuberous Pentanisia prunelloides and the geophyte Cyanotis speciosa. The vegetation is dominated by the grasses Themeda triandra and Tristachya leucothrix (Species Group M). The shrub Leucosidea sericea and forb Senecio inornatus (Species Group AL) are prominent. The grasses Eragrostis racemosa (Species Group M) and E. curvula (Species Group Y) are prominent in dense patches scattered throughout the area.

The sub-community occurs on rocky, grassed terrain on the Farm Platberg. Evidence of the impact of grazing by cattle and other smaller livestock, as well as their paths, is widespread. An average of 28 species per $100 \mathrm{~m}^{2}$ was recorded for the degraded community.

\section{Leucosidea sericea-Hyparrhenia hirta community}

The Leucosidea sericea-Hyparrhenia hirta community is located on the warm northern and north-western aspect, at 1930 to $2052 \mathrm{~m}$ above sea level, on steep to very steep slopes $\left(16^{\circ}\right.$ to $\left.45^{\circ}\right)$. Rock size varies from $<1 \mathrm{~mm}, 10$ to $50 \mathrm{~mm}$, with boulders $>200 \mathrm{~m}$. The community is located on Cave Sandstone with $<5 \%$ rock exposure on seasonally damp soils with depths ranging from 60 to $100 \mathrm{~mm}$ and $>300 \mathrm{~mm}$. Though no surface erosion was recorded, levels of trampling varied from none to heavy. The total percentage canopy cover for small trees was $5 \%$ to $10 \%$, and $5 \%$ for shrubs, while herbaceous cover ranged from $7 \%$ to $50 \%$.

The perennial grass Hyparrhenia hirta (Species Group N) was found to be characteristic for the community. The vegetation is dominated by the small tree Leucosidea sericea (Species Group $\mathrm{AL}$ ) and the grass Hyparrhenia hirta (Species Group N). The shrubs Calpurnia sericea (Species Group T) and Rhus discolor (Species Group P); the grass Eragrostis curvula (Species Group Y); and the forbs Senecio inornatus (Species Group AL) and Clutia affinis (Species Group AF) are prominent locally. An average of 28.7 species per $100 \mathrm{~m}^{2}$ was recorded in the six relevés.

\section{Rhus pyroides-Pteridium aquilinum community}

The shrub community occurs at low altitudes of between 1996 and $2034 \mathrm{~m}$ on the footslopes of the Platberg, on the southern and south-western aspects. The slope was found to vary from gradual to very steep. Soils are a mix of Cave Sandstone and igneous rocks. Rock cover ranges from $0 \%$ to $25 \%$, with no erosion or trampling seen. Soils are seasonally damp and 180 to $>300 \mathrm{~mm}$ deep. Canopy cover ranges between $70 \%$ and $95 \%$, and is dominated by the $1.8 \mathrm{~m}$ tall fern, Pteridium aquilinum.

The fern, Pteridium aquilinum (Species Group O), is diagnostic and dominant for this community. Prominent species include Calpurnia sericea (Species Group T) and Buddleja salviifolia (Species Group X); the perennial grass Eragrostis curvula; the shrub Rhus pyroides (Species Group Y); and the forb Senecio inornatus (Species Group AL).

Stands of the dense and distinct community, which show the invasion of the bracken into the grassland are indicative of disturbance (Du Preez 1991). Four relevés, with an average of 25.1 species per $100 \mathrm{~m}^{2}$ relevé, were recorded for the community.

\section{Diospyros whyteana-Euclea crispa community}

The community is located at altitudes between $1944 \mathrm{~m}$ and 2088 $\mathrm{m}$, on the north and north-eastern aspects, on moderately angled footslopes. Rock cover is $0 \%$ to $10 \%$ with stones > $200 \mathrm{~mm}$. Soils are generally $>300 \mathrm{~mm}$ deep, with some medium depth $(100$ to $120 \mathrm{~mm}$ ) sections. The geology is Cave Sandstone with scree rubble (a mixture of dolerite and basalt). Moderate to high levels of trampling and soil erosion were recorded. The canopy cover was found to be $20 \%$ to $70 \%$ for small trees and $10 \%$ to $40 \%$ for shrubs. The herbaceous cover is poor, and was found to vary between $0 \%$ and $5 \%$.

The community has a well-developed shrub layer, which is characterised by species from Species Group S, namely the shrubs Diospyros whyteana, Maytenus heterophylla, Euclea crispa, Rhus dentata, and Osyris lanceolata, and the weedy forbs Bidens pilosa and Achyranthus aspera var. sicula.

The vegetation is dominated by the shrubs Diospyros whyteana, Maytenus heterophylla, Euclea crispa (Species Group S), and Leucosidea sericea (Species Group AL). Prominent species include the shrubs Rhus dentata, Osyris lanceolata (Species Group S), Buddleja salviifolia (Species Group X), Heteromorpha arborescens, 
and Rhus pyroides, and the climber Dioscorea sylvatica (Species Group Y). The herbaceous layer is not well developed with the grass Eragrostis curvula (Species Group Y), as well as the understory grass Ehrharta erecta (Species Group AL), present. An average of 29.44 species per $100 \mathrm{~m}^{2}$ was recorded in 16 relevés.

Two sub-communities, including one with two variants, were identified:

\subsection{Diospyros whyteana-Euclea crispa-Bowiea volubilis sub-community}

The sub-community is located on mid-slopes at approximately $2100 \mathrm{~m}$ on the north, north-eastern and south-western aspects, with gradual to steep $\left(8^{\circ}\right.$ to $\left.26^{\circ}\right)$ slopes. The geology is Cave Sandstone, with scree derived from the higher igneous rocks. Rock cover varies between $0 \%$ and $10 \%$ on medium to deep (100 to $>300 \mathrm{~mm}$ ) soils. The surface erosion and levels of trampling are moderate to high. Total canopy cover for small trees ranges from $20 \%$ to $80 \%$, and that for shrubs from $0 \%$ to $40 \%$.

The rare Red Data geophytic climber Bowiea volubilis (Species Group Q) is characteristic of this community. The vegetation is dominated by three shrubs: Diospyros whyteana, Maytenus heterophylla, and Euclea crispa (Species Group S). Other prominent species include Rhus dentata (Species Group S), Buddleja salviifolia (Species Group X), Heteromorpha arborescens, and Rhus pyroides (Species Group Y). Forbs include the weedy Bidens pilosa and Achyranthus aspera sp sicula (Species Group S). The average number of species recorded per $100 \mathrm{~m}^{2}$ was 28.1.

The Diospyros whyteana-Euclea crispa-Bowiea volubilis subcommunity has two variants:

4.1.1 Maytenus undata variant: The shrub variant is characterised by species from Species Group R. The vegetation is dominated by the small trees Euclea crispa Maytenus heterophylla and Diospyros whyteana (Species Group S). The shrubs Maytenus undata (Species Group R), Buddleja salviifolia (Species Group X), Heteromorpha arborescens (Species Group Y), Rhamnus prinoides (Species Group AF), and Leucosidea sericea (Species Group AL) are prominent locally.

4.1.2 Bidens pilosa variant: The absence of species from Species Group R is characteristic. The vegetation is dominated by the shrubs Diospyros whyteana, (Species Group S), Buddleja salviifolia (Species Group X), Heteromorpha arborescens, and Rhus pyroides (Species Group Y) and the weed Bidens pilosa (Species Group S). Other prominent species include the shrubs Euclea crispa, Rhus dentata, and Maytenus heterophylla (Species Group S), and the weed Achyranthus aspera var. sicula (Species Group S)

\subsection{Diospyros whyteana-Euclea crispa-Themeda triandra sub-community}

The sub-community is located at relatively low altitudes of between $1940 \mathrm{~m}$ and $2084 \mathrm{~m}$ on the eastern, south-eastern and northern aspects. The slopes are moderate to steep. The bedrock geology is sandstone and shale of the Clarens Formation. The community is located on the foot or mid-slopes, with moderate to high levels of erosion and trampling. Rock exposure ranges between $0 \%$ and $10 \%$, with an exception of $25 \%$ for one relevé The soils are damp, with black humus $>300 \mathrm{~mm}$ deep. Woody species dominate the sub-community with the canopy cover for small trees ranging between $20 \%$ and $70 \%$, while shrubs have between $10 \%$ to $80 \%$ cover.

The sub-community is characterised by the absence of Species Groups $\mathrm{Q}$ and $\mathrm{R}$ and is dominated by the small trees and shrubs Diospyros whyteana, Maytenus heterophylla, Rhus dentata (Species Group S) and Leucosidea sericea (Species Group AL). Other prominent species include Buddleja salviifolia (Species Group X),
Heteromorpha arborescens, Eragrostis curvula, and Rhus pyroides, and the climbers Dioscorea sylvatica (Species Group Y), Clematis brachiata (Species Group AG), and Myrsine africana (Species Group AL). Within eight sample plots an average number of 30.75 species per $100 \mathrm{~m}^{2}$ was recorded.

\section{Kiggelaria africana-Crassula lanceolata community}

The Kiggelaria africana-Crassula lanceolata community is composed of tall to small trees and comprises a significan proportion $(27 \%)$ of the shrub/woody vegetation. It has two sub-communities, which are located on rocky ridges and scree slopes, predominantly on the south and south-west aspects, with scattered components on the south-eastern and northern slopes. The gradients are steep to very steep. The bedrock geology is sandstone and shale from the Clarens Formation, with the presence of igneous scree boulders $>500 \mathrm{~mm}$. Rock exposure ranges from $0 \%$ to $40 \%$. Altitudes range between 2006 $\mathrm{m}$ and $2238 \mathrm{~m}$. The soils are seasonally damp, shallow (10 to 100 $\mathrm{mm}$ ), or over $300 \mathrm{~mm}$ deep. Little or no trampling or erosion was found to be present. The canopy cover for small trees is between $5 \%$ and $15 \%$, and for tall trees is $25 \%$ to $80 \%$. There is a welldeveloped under-story layer of forbs and succulents, with cover varying between $15 \%$ and $75 \%$.

The community is characterised by species from Species Group V and comprises the tall tree Kiggelaria africana, the climber Zehneria scabra, and the succulent Crassula lanceolata sp. transvaalensis.

The vegetation has a well-developed tree and shrub layer, and is dominated by the tall tree Kiggelaria africana (Species Group V); the small tree Buddleja salviifolia (Species Group X); the shrub Rhus pyroides (Species Group Y); the tall, under-story forb Stachys grandifolia (Species Group AE); and the ubiquitous shrub Leucosidea sericea (Species Group AL). Other woody species with significant presence are Heteromorpha arborescens, Dioscorea sylvatica (Species Group Y), and the small shrub Myrsine africana (Species Group AL). The tall forb Senecio inornatus (Species Group $\mathrm{AL}$ ) is locally prominent. The grass layer is poorly developed, represented by only two grasses: Eragrostis curvula (Species Group Y) and Ehrharta erecta (Species Group AL). A total species count of 596 in 22 relevés averages 27.1 species per $100 \mathrm{~m}^{2}$.

\subsection{Kiggelaria africana-Crassula lanceolata-Senecio isatideus sub-community}

The Kiggelaria africana-Crassula lanceolata-Senecio isatideus subcommunity is located on the south and southwestern midslopes, with altitude ranging between $2006 \mathrm{~m}$ and $2219 \mathrm{~m}$. The slopes are steep to very steep. The bedrock geology is sandstone of the Clarens Formation and basalt at the contact of the summit volcanics. Rock exposure varies between $5 \%$ and $35 \%$. Surface erosion and trampling vary from zero to moderate. Soils are seasonally damp, shallow (20 to $200 \mathrm{~mm}$ ), or over $300 \mathrm{~mm}$ deep. The canopy cover for tall trees is $10 \%$, and for small trees is between $5 \%$ and $15 \%$. For shrubs, cover is between $20 \%$ and $75 \%$

The sub-community is characterised by the absence of species from Species Groups $\mathrm{U}, \mathrm{Z}$ and AC. The vegetation is dominated by the small tree Leucosidea sericea (Species Group AL), and the shrubs Buddleja salviifolia (Species Group X) and Stachys grandifolia (Species Group AE). The tree Kiggelaria africana (Species Group V) and the two grasses Eragrostis curvula (Species Group Y) and Ehrharta erecta (Species Group AL) have significant presence. Other species of importance include the tree Heteromorpha arborescens, the climber Dioscorea sylvatica (Species Group Y), and the tall forb Senecio inornatus (Species Group AL). An average of 31.29 different species per $100 \mathrm{~m}^{2}$ was recorded for the subcommunity.

\subsection{Kiggelaria africana-Crassula lanceolata-Zehneria scabra sub-community}

The sub-community is located on the extensive, mobile scree 
beds visible on the mid-slope at altitudes of between $2055 \mathrm{~m}$ and $2280 \mathrm{~m}$, on the cool south side of Platberg. The incline is steep to very steep. Very large boulders are common, with rock exposure ranging from $10 \%$ to $40 \%$. Soils are damp and generally shallow, with depths varying widely as a result of boulder packing. The geology is the contact between the Clarens Formation sandstone and the summit volcanics. No trampling or erosion is evident. Canopy cover for small trees varies between $5 \%$ and $15 \%$, and for shrubs between $30 \%$ and $90 \%$.

The sub-community is characterised by the presence of species from species Group U and includes Chrysocoma ciliate, Zantedeschia albomaculata, Polystichum monticola, Aeollanthus buchnerian, and Myosotis semiamplexicaulis. The vegetation is dominated by the trees Buddleja salviifolia (Species Group X), Kiggelaria africana (Species Group V), Rhus pyroides (Species Group Y), Stachys grandifolia (Species Group AE), and Leucosidea sericea (Species Group AL). Other species prominent in the subcommunity include the shrubs Myrsine africana (Species Group $\mathrm{AL}$ ), Rhus divaricata (Species Group AD), and Clematis brachiata (Species Group AG); and the forbs Senecio inornatus, Asparagus asparagoides, and A. microraphis (Species Group AL). The grass layer is poorly represented, with only Ehrharta erecta (Species Group AL) being present throughout.

The sub-community is a dense, shrub community, mostly located on the cool, moist south slopes of the Platberg. Individuals of the tree Kiggelaria africana are all below $6 \mathrm{~m}$ in height. The unstable substrate of igneous boulders has recently been colonised by plants. An average of 25.13 species per $100 \mathrm{~m}^{2}$ was recorded for the sub-community.

\section{Buddleja loricata-Rhus divaricata community}

The community is located on the southern side of the Platberg, at altitudes ranging between $2094 \mathrm{~m}$ and $2119 \mathrm{~m}$, on the extensive boulder scree slopes located on the steep to very steep shoulder below the summit basalt. The geology is sandstone bedrock, with the scree boulders composed of summit volcanics. Estimation of rockiness is difficult, as the communities are located almost exclusively on the vegetation growing on the accumulated, unstable boulders. Levels of trampling and erosion within the constraints of these communities range from zero to moderate. Soil depths vary greatly, depending on the location of the accumulated humus trapped by the boulders, from very shallow $(10 \mathrm{~mm})$ to $>300 \mathrm{~mm}$ deep. Canopy cover for tall trees ranges from $5 \%$ to $10 \%$, for small trees from $5 \%$ to $50 \%$ and for shrubs from $20 \%$ to $100 \%$. Herbaceous cover ranges from $1 \%$ to $50 \%$, with some relevés having up to $75 \%$ cover.

The community is defined by species from Species Group AD, including the shrubs Buddleja loricata and Rhus divaricata.

The community is dominated by the tree Leucosidea sericea (Species Group AL), the shrub Buddleja loricata (Species Group $\mathrm{AD}$ ), the tall under-story labiate forb Stachys grandifolia (Species Group AE), and the common climber Clematis brachiata (Species Group AG). The shrub Rhus divaricata (Species Group AG) is locally abundant. The paucity of grasses, forbs and geophytes for the community is a feature of the substrate, which is characterised by large, mobile boulders, which have very shallow, poorly developed soils. An average of 18.2 species per $100 \mathrm{~m}^{2}$ was recorded for the community.

\subsection{Buddleja loricata-Rhus divaricata-Gallium scabrelloides sub-community}

The sub-community is located at altitudes of between $2095 \mathrm{~m}$ and $2225 \mathrm{~m}$ on the cool, moist south slopes of the Platberg, below the vertical igneous rocks on the steep to very steep slopes. Very large packed boulders comprise the scree community. Soils are damp, very shallow $(10 \mathrm{~mm})$ or $>300 \mathrm{~mm}$ deep. Canopy cover varies from $10 \%$ to $20 \%$ for tall trees, $5 \%$ to $60 \%$ for small trees and $20 \%$ to $80 \%$ for shrubs.
The sub-community is characterised by two species from Species Group AA: the soft, lax forb Galium scabrelloides and the fern Polystichum pungens.

The dominant species include the tree Leucosidea sericea (Species Group AL), the shrub Buddlejaloricata (Species Group AD), the forb Stachys grandiflora (Species Group AE), and the climber Clematis brachiata (Species Group AG). There is poor representation of grasses, geophytes and forbs. The sub-community is regarded as species poor, with an average of 18.1 species per $100 \mathrm{~m}^{2}$, which is the second lowest average for the woody shrub vegetation. The loose packing and precarious nature of the boulders, with very shallow soils, partially explains the paucity.

\subsection{Buddleja loricata-Rhus divaricata-Stachys grandifolia sub-community}

The sub-community is located on the mid-slope, at approximately $2200 \mathrm{~m}$ on the southern aspect, with steep to very steep slopes. The geology is sandstone of the Clarens Formation and scree boulders of the Stormberg Volcanics. Scree boulders give rock exposure of between $10 \%$ and $20 \%$, with soil depths ranging from shallow $(10 \mathrm{~mm})$ to $>300 \mathrm{~m}$ deep. Moderate trampling and erosion was recorded. Canopy cover ranges between $50 \%$ and $95 \%$ for shrubs. Evidence of fire is apparent, with the remains of burned tree stumps and shrubs.

The sub-community is characterised by the single species Asparagus plumosus (Species Group AC) and is dominated by the shrub Buddleja loricata (Species Group AD), and the under-story forb Stachys grandifolia (Species Group AE). Other prominent species include the tree Leucosidea sericea (Species Group AL), the shrubs Rhus divericata (Species Group AD) and Polygala virgata (Species Group AF), and the climber Clematis brachiata (Species Group AG). No grasses or geophytes are present, indicating a depaupered species community. Such depauperisation is also reflected in the low average of 17.5 species recorded per $100 \mathrm{~m}^{2}$.

6.2.1 Clutia hirsuta variant: While characterised by species from Species Group AB, the vegetation is dominated by the shrub Buddleja loricata (Species Group AD), and the two labiate forbs Stachys grandifloria (Species Group $\mathrm{AE}$ ) and Plectranthus grallatus (Species Group AG).

6.2.2 Stachys grandifolia variant: The variant is differentiated from the Clutia hirsuta variant by the absence of species from Species Group AB. The vegetation is poorly developed, but dominated by the shrub Buddleja loricata (Species Group AD), and the labiate forb Stachys grandifolia (Species Group AE).

\section{Leucosidea sericia-Asparagus ramosissimus community}

The community is located on a north-western and south-eastern aspect, at altitudes ranging between $2015 \mathrm{~m}$ and $2236 \mathrm{~m}$. The community is located on the footslope leading to the locally named 'Monkey Point', and on the south-eastern section of the promontory. The slope varies from gradual for the Leucosidea sericia woodland to very steep for the south-east community. Soils are a mix of damp, black turf and humus $>500 \mathrm{~mm}$ deep. Levels of trampling are moderate, with little erosion. Large boulders cover the forest floor, with some sandstone sheet rock on the south-eastern side giving exposure up to $10 \%$. Geology is sedimentary Cave Sandstone of the Clarens Formation. Canopy cover for tall trees is between $5 \%$ and $25 \%$, for small trees between $20 \%$ and $80 \%$, and for shrubs between $15 \%$ and $80 \%$. The herbaceous cover ranges from $20 \%$ to $70 \%$.

The community is characterised by species from Species Group AI, including the lithophytic fern Pleopeltis macrocarpha; the forbs Asparagus ramosissimus, Parietaria debilis, and Streptocarpus polyantha; and the climber Riocreuxia torulosa.

The tree species Kiggelaria africana (Species Group V) and Leucosidea sericea (Species Group AL) dominate the vegetation. Other species present include Plectranthus grallatus (Species 
Group AG), and Parietaria debilis (Species Group AI); the small shrub Myrsine Africana; and the under-story grass Ehrharta erecta (Species Group AL). An average of 25.8 species per $100 \mathrm{~m}^{2}$ was recorded for the community, which is significantly lower than has been recorded for similar communities by Bredenkamp and Brown (2003), Grobler et al. (2002) and Robbeson (1998).

The community has two sub-communities:

\subsection{Asparagus ramosissimus-Leucosidea sericea- Fraxinus angustifolia sub-community}

The sub-community is located on the footslope below the Cave Sandstone of the Clarens Formation, on the north-western and south-eastern aspects. Soils are deep, black and damp, with depths greater than $500 \mathrm{~mm}$. Igneous boulders cover less than $5 \%$ of the area. The sub-community is a forest stand with a $25 \%$ cover provided by tall trees, $60 \%$ for small trees, and $10 \%$ for shrubs. Slopes vary from $0^{\circ}$ to $8^{\circ}$, with moderate levels of erosion and trampling evident. The forest floor is transsected by numerous trails, indicating significant use by wildlife. The trees form a community with poorly developed stratification. The forest patch is mostly open below the tall trees, with limited tree and shrub growth. Low, caespitose forbs cover the ground. Speciation is low, with $>50 \%$ bare soil.

The sub-community is characterised by species from Species Group AH, including the alien tree Fraxinus angustifolia; the forbs Solaum macrocarpon and Cerastium indicum; the grass Bromus leptocladus; and the sedge Schoenoxphium lehmannii.

The vegetation is dominated by the tall tree Fraxinus angustifolia (Species Group AH); the small tree Leucosidea sericea (Species Group AL); the shrubs Rhus divaricata (Species Group AD) and Myrsine africana (Species Group AL); and the forb Stachys grandifolia (Species Group AE). Prominent species include the tree Kiggelaria africana (Species Group V); the weedy forb Achyranthus aspera var. sicula (Species Group S); and the two grasses Bromus leptocladus (Species Group $\mathrm{AH}$ ) and Ehrharta erecta (Species Group AL). The average number of species recorded per $100 \mathrm{~m}^{2}$ was 16.7, which was the lowest count for all the communities.

Fraxinus angustifolia an alien emergent tree, which, along with Leucosidea sericea, forms the major component of the forest. Some of the Leucosidea sericea individuals are more than $6 \mathrm{~m}$ tall, with DBH of $500 \mathrm{~mm}$ forming an unusually tall and dense stand of Leucosidea trees. Lithophytes and ferns cover numerous large igneous boulders. The forest has a $90 \%$ to $100 \%$ canopy cover. Sunlight penetrates gaps in the canopy with numerous thickstemmed (20 to $50 \mathrm{~mm}$ ) climbers, mostly Clematis brachiata festooning the trees.

\subsection{Asparagus ramosissimus-Leucosidea sericea Plectranthus grallatus sub-community}

The sub-community is located on the cool and very cool southeastern aspects of the Platberg on private farms. The subcommunity extends from the footslopes, on gradual to very steep slopes on the mid-slope below the cliffs. Soils are deeper than $500 \mathrm{~mm}$, and are damp, composed of black humus-rich soil, which shows moderate erosion and trampling. Altitudes vary from $2030 \mathrm{~m}$ to $2250 \mathrm{~m}$. Rockiness is less than $5 \%$. The geology is a mix of Cave Sandstone of the Clarens Formation and the igneous rock capping Platberg. The canopy cover for tall trees is $25 \%$. For small trees cover it is $60 \%$, and for shrubs it is $10 \%$. The dense forest patch covers the very steep eastern slope of the Platberg. It forms a well-stratified forest community with a mix of emigrants $(>6 \mathrm{~m})$, small trees and shrubs, with numerous ferns, forbs, soft grasses and lichens abundant on boulders and dead trees. Browsing and other animal utilisation is evident. Though three Podocarpus latifolius individuals have been recorded in the community (M. Cunningham, pers comm., 2005), none were found in the current study.

The species from Species Group AJ characterise the community, including the forb Cineraria dieterlenii; the large fern Polystichum wilsonii; and the geophyte Kniphofia caulescens.
The sub-community is dominated by the tall tree Rhamnus prinoides (Species Group AF); the small tree Leucosidea sericea (Species Group AL); the shrub Buddleja salviifolia (Species Group $\mathrm{X}$ ); the under-story forb Plectranthus grallatus (Species Group AG); the soft prostrate herb Parietaria debillis; and the spiny forb Asparagus ramosissimus (Species Group AI). An average of 23 species per $100 \mathrm{~m}^{2}$ was recorded for the community.

\section{Senecio inornatus-Thamnocalamus tessellatus community}

The community is located exclusively on the cool, southern side of the Platberg, between altitudes of $2220 \mathrm{~m}$ and $2316 \mathrm{~m}$. It occurs in steep ravines and watercourses, along the base of the cliffs and growing along the only perennial stream in Donkey Pass. The lowest altitude at which Thamnocalamus tessellatus has been recorded is $1980 \mathrm{~m}$, in a south-facing gully. The community is in semi-shade, on gradual to steep inclines with black, damp soils, ranging from $100 \mathrm{~mm}$ to $>300 \mathrm{~mm}$ deep. Rock exposure is mostly zero, although certain sections have $20 \%$ to $30 \%$ cover. Canopy cover for shrubs and bamboo $2 \mathrm{~m}$ to $3.5 \mathrm{~m}$ tall ranges between $20 \%$ and $50 \%$. Such cover shades out most other species and, with its dense, tight rhizomal packing, inhibits the root growth of other species. The result is a low herbaceous cover, ranging between $1 \%$ and $30 \%$.

The community is characterised by species from Species Group AK, being composed of the monotypic genus of mountain bamboo Thamnocalamus tessellates; the endemic shrub Euryops evansii; and the forbs Alepedia amatymbica and Helichrysum hypoleucum.

The community is dominated by Thamnocalamus tessellatus (Species Group AK). Other prominent species include the tree Leucosidea sericea (Species Group AL), the shrubs Euyrops evansii (Species Group AK) and Myrsine africana (Species Group AL); and the forbs Alepidea amatymbica (Species Group AK) and Senecio inornatus (Species Group AL).

Thamnocalamus tessellatus forms stands, with poor representation from other species. An average of 23 species per $100 \mathrm{~m}^{2}$ was recorded. Shading out by the bamboo, as well as dense rhizome development, which outcompetes other species, may explain the limited development of other vegetation in the community (Gibbs-Russell et al. 1991; Moffett 1997). Such development is the second lowest after the Buddleja loricata-Rhus divericata community 6.2, which is located on large, loose, poorly packed boulders with shallow, thin soils.

\section{DISCUSSION}

The results from the phytosociological analysis indicate the woody shrub vegetation to have a variety of plant communities, which are dominated by i) tall and short perennial bunch grasses, in full sun, on moderate slopes, on rocky terrain, with shallow, well-drained soils, which comprise either grassland in transition or established woody/shrub communities (Communities 1, 2 and 3); and ii) trees and shrubs in well-developed shaded stands,

TABLE 2

Average number of species for each of the major communities

\begin{tabular}{lcc}
\hline COMMUNITY NAME & $\begin{array}{c}\text { COMMUNITY } \\
\text { NUMBER }\end{array}$ & $\begin{array}{c}\text { AVERAGE } \\
\text { SPECIES PER } \\
\mathbf{1 0 0}^{\mathbf{2}}\end{array}$ \\
\hline Themeda triandra-Watsonia lepida & 1 & 32.2 \\
Diospyros whyteana-Euclea crispa & 4 & 29.4 \\
Leucosidea sericea-Hyparrhenia hirta & 2 & 28.7 \\
Kiggelaria africana-Crassula lanceolata & 5 & 27.1 \\
Asparagus ramosissimus-Leucosidea sericia & 7 & 25.8 \\
Rhus pyroides-Pteridium aquilinum & 3 & 25.1 \\
Senecio inornatus-Thamnocalamus tessellatus & 8 & 23 \\
Buddleja loricata-Rhus divericata & 6 & 18.2 \\
\hline
\end{tabular}


on steep slopes, mainly on the southern and eastern aspects, with specialist under-story forbs and grass species (Communities 4 to 8) on deep, damp organic-rich soil.

The Themeda triandra-Watsonia lepida community (Community $1)$, which constitutes the largest component of the Shrubland vegetation, was found to have the greatest average number of species ( 32 per $100 \mathrm{~m}^{2}$ ) (see Table 2 ). The woody shrub vegetation of the community is possibly an extension of the Western Lesotho Basalt Shrubland (Gd 9; Mucina \& Rutherford 2006), which has a similar species composition, with typical species, such as Leucosidea sericea, Rhamnus prunoides and Buddleja salfolia, which are indicative of forest precursors. However, the woody vegetation on Platberg may be more complex than the Western Lesotho Basalt Shrubland described by Mucina \& Rutherford. The former represents a biogeographic relictual situation, starting in the Miocene, with climate cooling and the rise and dominance of Grassland (Retallack 1992, 2001), with the Western Lesotho Basalt Shrubland unit (Gd 9; Mucina \& Rutherford) showing the transition of woody shrubland to grassland. Such a finding is supported by the presence of the C4 grass Themeda triandra, which is adapted to warmer drier conditions (GibbsRussell et al. 1991), dominating the northern and western slopes with the shrub Leucosidea sericea dominant/prominent on all slopes throughout Platberg (Table 1). Thus, the zone may be one of tension between the grassland and woody shrubland habitats, in accordance with which the zone or gradient allows for high species diversity patterns (Cowling 1992; Linder 2003). Such may also be the case for the Diospyros whyteana-Euclea crispa community (See Community 4, as represented in Table $1)$, which is closely related to the Basotho Montane Shrubland vegetation unit (Gm 5; Mucina \& Rutherford). The vegetation unit is embedded, or at least closely related to, the Western Lesotho Basalt Shrubland. The rainfall, altitude, and temperature recorded for the study area closely resemble those of the Western Lesotho Basalt Shrubland (Gd 9; Mucina \& Rutherford), with the latter shrubland being confined to the Maseru and Mafekeng Districts. The community studied might therefore be regarded as an extension of the vegetation on Platberg.

The lowest species richness is seen in the Buddleja loricata-Rhus divericata community (Community 6) with 18.2 species per 100 $\mathrm{m}^{2}$ (see Table 2). Such paucity might reflect the shallowness of the soils occurring on the mobile boulder beds, as well as the high incidence of fire observed in the field.

Though no Protea shrubs grow on Platberg, some have been recorded in the proximity of the Golden Gate National Park (Roberts 1969) and $60 \mathrm{~km}$ to the south, in Qwa-Qwa (Moffett et al. 2001), KwaZulu-Natal (Robbeson 1998), the northern Drakensberg (Matthews 1991; Matthews, Bredenkamp \& Van Rooyen 1994; Matthews et al. 2001), and the southern Drakensberg (Bester 1998; Hill 1996; Smit et al. 1993, 1997; Smit, Bredenkamp \& Van Rooyen 1995). Specimens of Protea caffra, P. subvestita and $P$. roupelliae were also collected near Sterkfontein Dam, approximately $25 \mathrm{~km}$ to the south of Platberg in 2003, 2004, and 2005 (Brand 2007).

\section{Affinities with Platberg}

Numerous phytosociological and floristic studies of the vegetation of the grassland biome in the Free State (Du Preez 1991; Du Preez \& Bredenkamp 1991a, 1991b; Fuls 1993; Kay, Bredenkamp \& Theron 1993; Malan 1998; Matthews et al. 1994; Moffett et al. 2001; Perkins 1997; Perkins et al. 1999a; Roberts 1969; Van Zinderen Bakker 1973), KwaZulu-Natal (Hill 1996; Killick 1978a, 1978b; Robbeson 1998; Smit et al. 1993, 1995, 1997), the Eastern Cape (Bester 1998; Hoare \& Bredenkamp 2001; Pond et al. 2002), Gauteng (Bredenkamp \& Brown 2003; Grobler et al. 2002; Grobler, Bredenkamp \& Brown 2006), Limpopo (Barrett et al. 2006), and Mpumalanga (Brown et al. 2005; Matthews 1991: Matthews et al. 1994) demonstrate floristic relationships.
Studies conducted by Bester (1998), Fuls (1993) and Matthews (1991) also show floristic relationships with Platberg. As discussed by White (1983) and Bester (1998), the high-altitude Afromontane, Altimontane regions of Africa can be regarded as an archipelago-like string of islands. The theoretical model of Macarthur \& Wilson (2001) and Hubbell (2001) predicts that the closer the islands are, the greater the alpha diversity. Thus, it might be expected that the studies of high-altitude vegetation for Qwa-Qwa (Moffett et al. 2001) and the Golden Gate National Park (Kay et al. 1993; Roberts 1969) would show a similar species composition and diversity. The species lists for the cool eastern portions of the areas in question show a high degree of similarity with taxa from Platberg. Such a high degree of similarity might have been established before the fragmentation of the Afromontane Podocarpus forests (Mucina \& Rutherford 2006).

Other close floristic associations exist with the Korannaberg (Du Preez 1992; Du Preez \& Bredenkamp 1991b), which is the only other inselberg on which a similar study has been conducted. The Korannaberg is approximately $300 \mathrm{~km}$ west of Platberg, in the drier interior of the Eastern Free State. It is also at the lower altitude of $1881 \mathrm{~m}$ (Du Preez \& Bredenkamp 1991a, 1991b), and has no basaltic cap. Precipitation is lower, at approximately 550 mm per annum or more (Du Preez \& Bredenkamp 1991a, 1991b). The Korannaberg falls outside the defined Afromontane zone (Hilliard \& Burtt 1987; Mucina \& Rutherford 2006; Van Wyk \& Smith 2001 2003; White 1983); however, an examination of the species list and phytosociological vegetation tables shows many similarities with Platberg (Brand 2007).

In addition, Leucosidea sericea, which is a significant woody/ shrub component on Platberg, is found commonly along streams in the Mountain Zebra National Park (MZNP). The two woody shrubs, Maytenus heterophylla and Diospyros whyteana, are also found in association with the Renosterveld (Pond et al. 2002).

\section{CONCLUSION}

No previous vegetation description has been completed for Platberg. The description of the shrubland is part of a larger study that has been conducted into the entire vegetation of Platberg, which has been identified as one of four distinct major communities (i.e. Wetlands, Shrubland, Grassland and Fynbos) occurring on the inselberg (Brand 2007).

The study resulted in the identification of 20 plant communities, which can be grouped into eight major communities, 13 subcommunities and eight variants. A total of 450 species, belonging to 304 genera and 95 families, was identified for the Shrubland. A total of 24 endemic or near-endemic and Red Data species belonging to the Drakensberg Alpine Centre (DAC) and the broader Eastern Mountain Region (EMR) (Carbutt \& Edwards 2004, 2006) was collected, along with 22 invasive, or potentially invasive, alien species. A species to hectare ratio of 4.37 (43.67 per $\mathrm{km}^{2}$ ) was calculated, indicating a moderately rich floristic composition.

The shrub community on Platberg is located on the rocky ridgeline or boulder outcrops on the summit, as well as along the benches on the vertical cliffs, at their bases and in gullies, drainage lines and on scree slopes on all aspects of the inselberg. Generally, the woody shrub community is low to medium in height (2 to $6 \mathrm{~m})$, with a predominance of Leucosidea sericea occurring throughout and dominating in communities 1, 2, 6 and 7. Although L. sericea is generally found as a small tree or shrub in the study area, it does reach heights over $6 \mathrm{~m}$ in some areas. Though the taller Podocarpus latifolius (M. Cunningham, pers. comm., June 2007) has been reported as growing on the cool eastern slopes of Platberg, none was found during the study.

The presence of the endemic bamboo, Thamnocalamus tessellates, in South Africa shows the phytogeographic link with this genus and the other five related species, which occur in the Himalayas 
(Pooley 2003). The mountain bamboo, Thamnocalamus tessellates, occurs as a disjunct population on the Drakensberg in South Africa, as well as on the mountains, including especially Mount Kilimanjaro, in East Africa. Four species of such mountain bamboo exist, of which there are three genera in east Africa. One genus, Arundinaria tessellate, is synonymous with Thanmocalamus tessellatus. The nearest member of the genus occurs in the Himalayas, suggesting that it evolved there during the formation of Gondwanaland (White 1983). According to Gibbs-Russell et al. (1991), the Himalayan synonym genus is Himalayacalamus.

The Basotho Montane Shrubland (Gm 5) unit is regarded as vulnerable, with the conservation target of $28 \%$ being regarded as desirable. Currently, it is only $2 \%$ conserved in the Qwa-Qwa National Park section of the Golden Gate Highlands National Park, as well as in the Sterkfontein Dam Nature Reserve (Mucina \& Rutherford 2006). The Gd 9 Western Lesotho Basalt Shrubland (Gd 9) is currently not conserved in any reserve, with $16 \%$ having probably already been transformed by agriculture (Mucina \& Rutherford). On Platberg, where both units are found growing in an interpenetrated union, there is ample opportunity for conservation of such co-joined vegetation units.

The floristic collections and the plant community analysis shows Platberg to be an important centre for plant diversity, with high species richness, and a variety of habitats and complex ecosystems. Accordingly, conservation of the site should be prioritised, with a management plan being developed for such express purpose.

The study described in the present article will provide valuable baseline data on the ecosystems of Platberg. Such data will be incorporated into the management plan for the Platberg Conservancy, as well as be used to augment the larger MalotiDrakensberg Transfrontier Park Project, the surveys of which are currently being concluded. The data will form part of the biodiversity surveys of the Free State Department for Economic Tourism, and Environmental Affairs. Such data will assist the Department in setting criteria for protecting and managing unique flora and inselbergs in the province.

\section{ACKNOWLEDGEMENT}

Without the generous funding granted by the National Geographic (grant number 7920-05), the current fieldwork and study would not have been possible.

\section{NOTE}

Supplementary information for this paper is available from www.koedoe.co.za article \#696: Table 1.

\section{REFERENCES}

Acocks, J.P.H., 1988, 'Veld types of South Africa', Memoirs of the Botanical Survey of South Africa 57, 1-146.

Barbour, M.G., Burk, J.H. \& Pitts, W.D., 1987, Terrestrial plant ecology, 2nd edn., Benjamin/Cummings Publishing Company, Inc., San Francisco.

Barrett, A.S., Brown, L.R., Barrett, L. \& Henzi, S.P., 2006, 'Phytosociological and plant community utilisation by vervet monkeys of the Blydeberg Conservancy, Limpopo Province', Koedoe 49(1), 49-68.

Bester, S.P., 1998, 'Vegetation and flora of the Southern Drakensberg Escarpment and adjacent areas', MSc thesis, Department of Botany, University of Pretoria.

Brand, R.F., 2007, 'Phytosociology of Platberg Mountain, eastern Free State, South Africa', PhD thesis, Department of Plant Sciences, University of the Free State.

Brand, R.F., Du Preez, P.J. \& Brown, L.R., 2008, 'A floristic description of the Afromontane fynbos communities on Platberg, Eastern Free State, South Africa', Koedoe 50(1), 202-213.

Bredenkamp, G.J. \& Brown, L.R., 2003, 'A reappraisal of Acocks' Bankenveld: Origin and diversity of vegetation types', South African Journal of Botany 69(1), 7-26.
Brown, L.R., Marais, H., Henzi, S.P. \& Barrett, L., 2005, ‘Vegetation classification as the basis for baboon management in the Bourke's Luck Section of the Blyde Canyon Nature Reserve, Mpumalanga', Koedoe 48(2), 71-92.

Carbutt, C. \& Edwards, T.J., 2006, 'The endemic and nearendemic angiosperms of the Drakensberg Alpine Centre', South African Journal of Botany 72, 105-132.

Carbutt, C. \& Edwards, T.J., 2004, 'The flora of the Drakensberg Alpine Centre', Edinburgh Journal of Botany 60(3), 581-607.

Cowling, R.M. (ed.), 1992, The ecology of fynbos: Nutrients, fire and diversity, Oxford University Press, Cape Town.

Du Preez, P.J. \& Bredenkamp, G.J., 1991a, 'The syntaxonomy and synecology of the forests in the eastern Orange Free State, South Africa ll: The Pittosporetatea viridiflorum', South African Journal of Botany 57, 198-206.

Du Preez, P.J. \& Bredenkamp, G.J., 1991b, ‘Vegetation classes of the southern and eastern Orange Free State, (Republic of South Africa) and the highlands of Lesotho', Navors. Nas. Mus. Bloemfontein 7, 477-526.

Du Preez, P.J., 1991, 'A syntaxonomical and synecological Study of the vegetation of the South-Eastern Orange Free State and related areas with special reference to Korannaberg', $\mathrm{PhD}$ thesis, Department of Plant Sciences, University of the Orange Free State.

Du Preez, P.J., 1992, 'The classification of the vegetation of Korannaberg, eastern Orange Free State. I. Afromontane fynbos communities', South African Journal of Botany 58(3), $165-172$.

Du Toit, A.L., 1956, The geology of South Africa, Oliver and Boyd, Edinburgh.

Fuls, E.R., 1993, 'Vegetation ecology of the northern Orange Free State', PhD thesis, Department of Botany, University of Pretoria.

Germishuizen, G. \& Meyer, N.L. (eds.), 2003, ‘Plants of southern Africa: An annotated checklist', Strelitzia 14, n.p.

Gibbs-Russell, G.E., Watson, L., Koekemoer, M., Smook, L. Barker, N.P., Anderson, H.M. \& Dallwitz, M.J., 1991, 'Grasses of Southern Africa', Memoirs of the Botanical Survey of South Africa 58, n.p.

Grobler, C.H., Bredenkamp, G.J. \& Brown, L.R., 2002, 'Natural woodland vegetation and plant species richness of the urban open spaces in Gauteng, South Africa', Koedoe 45(1), n.p.

Grobler, C.H., Bredenkamp, G.J. \& Brown, L.R., 2006, ‘Primary grassland communities of the urban open spaces in Gauteng, South Africa', South African Journal of Botany 72, 367-377.

Hennekens, S.M., 1996a, TURBOVEG: A software package for input, processing, and presentation of phytosociological data, User's guide, version 2001, University of Lancaster, IBN-DLO.

Hennekens, S.M., 1996b, MEGATAB: A visual editor for phytosociological tables, Giesen \& Geurts, Ulft.

Hill, M.O., 1979, TWINSPAN - a FORTRAN program for arranging multivariate data in an ordered two-way table by classification of the individuals and attributes, Cornell University, Ithaca.

Hill, T.R., 1996, 'Description, classification and ordination of the dominant vegetation communities, Cathedral Peak, KwaZulu-Natal Drakensberg', South African Journal of Botany $62,263-269$

Hilliard, O.M. \& Burtt, B.L., 1987, The botany of Southern Natal Drakensberg, National Botanical Gardens, Cape Town.

Hoare, D.B. \& Bredenkamp, G.J., 2001, 'Syntaxonomy and environmental gradients of the grasslands of the Stormberg/ Drakensberg mountain region of the Eastern Cape, South Africa', South African Journal of Botany 67, 595-608.

Hubbell, S.P., 2001, The unified neutral theory of biodiversity and biogeography, Princeton University Press, Princeton.

Huntley, B.J., 1991, 'Challenges to maintaining biotic diversity in a changing world', in B.J. Huntley (ed.), Biotic Diversity in Southern Africa, pp. xii-xix, Oxford University Press, Cape Town.

Kay, C., Bredenkamp, G.J. \& Theron, G.K., 1993, 'The plant communities of the Golden Gate Highlands National Park in the north-eastern Orange Free State', South African Journal of Botany 59(4), 442-449. 
Kent, M. \& Coker, P., 1992, Vegetation description and analysis: A practical approach, John Wiley \& Sons, Chichester.

Killick, D.J.B., 1963, 'An account of the plant ecology of the Cathedral Peak area of the Natal Drakensberg', Memoirs of the Botanical Survey of South Africa 34, n.p.

Killick, D.J.B., 1978a, 'The Afro-alpine Region', in M.J.A. Werger (ed.), Biogeography and Ecology of Southern Africa, pp. 515-560, Junk, The Hague.

Killick, D.J.B., 1978b, 'Notes on the Vegetation of the Sani Pass Area of the Southern Drakensberg', Bothalia 12, 537-542.

King, L.C., 1963, South African scenery: A textbook of geomorphology, 3rd edn., Oliver and Boyd, Edinburgh.

Körner, C., 2003, Alpine plant life: Functional plant ecology of high mountain ecosystems, Springer-Verlag, Berlin.

Land Type Survey Staff, 1991, Land types of the map 2828 Harrismith, Soil and Irrigation Research Institute, Department of Agriculture, Pretoria.

Linder, H.P., 2003, The radiation of the Cape flora, southern Africa, Biological Review 78, 597-638.

Low, A.B. \& Rebelo, A.G. (eds.), 1998, Vegetation of South Africa, Lesotho and Swaziland, Department of Environmental Affairs \& Tourism, Pretoria.

Macarthur, R.H. \& Wilson, E.O., 2001, The theory of island biogeography, Princeton University Press, Princeton.

MacVicar, C.N., Loxton, R.F., Lambrechts, J.J.N., Le Roux, J., De Villiers, J.M., Verster, E., Merrweather, F.R., Van Rooyen, T.H. \& Von M., H.J., 1991, Soil Classification: A taxonomic system for South Africa, Department of Agricultural Development, Soil and Irrigation Research Institute, Pretoria.

Malan, P.W., 1998, 'Vegetation ecology of the Southern Free State', PhD thesis, University of the Orange Free State.

Matthews, W.S., 1991, 'Phytosociology of the North-eastern Mountain Sourveld', MSc thesis, University of Pretoria.

Matthews, W.S., Van Wyk, A.E., Van Rooyen, N. \& Botha, G.A., 2001, 'Vegetation of the Tembe Elephant Park, Maputoland, South Africa', South African Journal of Botany 67, L 573-594.

Matthews, W.S., Bredenkamp, G.J. \& Van Rooyen, N., 1994, 'The phytosociology and syntaxonomy of relatively low-altitude areas in the North-Eastern Mountain Sourveld, in the eastern Transvaal escarpment region', Koedoe 37(2), 73-87.

McCarthy, T. \& Rubidge, B., 2005, The story of Earth $\mathcal{E}$ life, Struik Publishing, Cape Town.

Millennium Ecosystem Assessment, 2005, Ecosystems and human well-being: Biodiversity synthesis, World Resources Institute, Washington, DC.

Moffett, R., 1997, Grasses of the Eastern Free State, UNIQUA, Qwa-Qwa Campus of the University of the North, Phuthaditjhaba.

Moffett, R.O., Daemane, M.E., Pitso, T.R., Lentsoane, R. \& Taoana, T.R.N., 2001, 'A checklist of the vascular plants of Qwa-Qwa and notes on the flora and vegetation of the area', UNIQWA Research Chronicles 3(2), 32-83.

Mucina, L. \& Rutherford, M.C., 2006, 'The vegetation of South Africa, Lesotho and Swaziland', Strelitzia 19, n.p.

Mueller-Dombois, D. \& Ellenberg, H., 1974, Aims and methods of vegetation ecology, J. Wiley \& Sons, New York.

Mutke, J., Kier, G., Braun, G., Schultz, C.H.R. \& Barhlott, W., 2001, 'Patterns of African vascular plant diversity - a GIS based analysis', Systematics and Geography of Plants 71, 1125-1136.

Norman, N. \& Whitfield, G., 1998, Geological journeys: A traveller's guide to South Africa's rocks and landforms, De Beers, s.l.

Parmentier, I., Oumorou, M., Porembski, M., Lejoly, S. \& Decocq, G.J., 2006, 'Ecology, distribution, and classification of xeric monocotyledonous mats on inselbergs in West Africa and Atlantic central Africa', Phytocoenology 36(4), 547-564.
Perkins, L., 1997, 'Aspects of the syntaxonomy and synecology of the grasslands of southern KwaZulu-Natal', MSc thesis, Department of Botany, University of Pretoria.

Perkins, L., Bredenkamp, G.J. \& Granger, J.E., 1999a, 'The phytosociology of the incised river valleys and dry upland savannah of the southern KwaZulu-Natal', South African Journal of Botany 65(5\&6), 321-330.

Pond, U., Beesley, B.B., Brown, L.R. \& Bredenkamp, H., 2002, 'Floristic analysis of the Mountain Zebra National Park, Eastern Cape', Koedoe 45(1), n.p.

Pooley, E., 2003, Mountain flowers: A field guide to the flora of the Drakensberg and Lesotho, Flora Publishing Trust, Durban.

Porembski, S. \& Brown G., 1995, 'The vegetation of inselbergs in the Comoé National Park (Ivory Park)', Conservatoire et Jardin Botanicues de Geneve 50(2), 351-365.

Retallack, G.J., 1992, 'Middle Miocene fossil plants from Fort Ternan (Kenya) and evolution of African grassland', Paleobiology 18(4), 383-400.

Retallack, G.J., 2001, 'Cenozoic expansion of grasslands and climate cooling', The Journal of Geology 109, 407-426.

Robbeson, R.A.J., 1998, 'Phytosociology of northwestern KwaZulu-Natal', MSc thesis, Department of Botany, University of Pretoria.

Roberts, B.R., 1969, 'The vegetation of the Golden Gate Highlands National Park', Koedoe 12, 15-28.

Sarthou, C. \& Villiers, J-F., 1998, 'Epilithic plant communities on inselbergs in French Guiana', Journal of Vegetation Science 9, 847-860.

Schulze, R.E., 1997, South African atlas of agro hydrology and climatology, Water Research Commission, Pretoria. (Report TT 82/96.)

Smit, C.M., Bredenkamp, G.J. \& Van Rooyen, N., 1993, 'Phytosociology of the Ac land type in the foothills of the low Drakensberg in north-western Natal', South African Journal of Botany 59, 203-214.

Smit, C.M., Bredenkamp, G.J. \& Van Rooyen, N., 1995, 'The grassland vegetation of the low Drakensberg Escarpment in the north-western KwaZulu-Natal and north-eastern Orange Free State Border Area', South African Journal of Botany 61, 9-17.

Smit, C.M., Bredenkamp, G.J., Van Rooyen, N., Van Wyk, A.E. \& Combrink, J.M., 1997, 'Vegetation of the Witbank Nature Reserve and its importance for conservation of threatened Rocky Highveld Grassland', Koedoe 40(2), n.p.

South African Weather Services, 2007, Climate of South Africa: Climate statistics for Bethlehem from 1961-1990, WB 40, Government Printer, Pretoria.

Taylor, D., 1996, 'Mountains', in W.M. Adams, A.S. Goudie \& A.R. Orme (eds.), The Physical Geography of Africa, pp. 287306, s.l., Oxford University Press.

Van Wyk, A.E. \& Smith, G.F., 2001, Regions of floristic endemism in Southern Africa: A review with emphasis on succulents, Umdaus Press, Pretoria.

Van Zinderen Bakker Jr., E.M., 1973, 'Ecological investigation of forest communities in the Eastern Orange Free State and the adjacent Natal Drakensberg', Vegetatio 28, 299-334.

Westhoff, V. \& Van der Maarel, E., 1980, '20 The Braun-Blanquet approach', in R.H. Whitaker (ed.), Classification of Plant Communities, pp. 287-378, Junk, The Hague.

Whitaker, R.H. (ed.), 1980, Classification of plant communities, Kluwer Academic Publisher, The Hague.

White, F., 1983, The vegetation of Africa. Volume XX, A descriptive memoir to accompany the UNESCO/AETFAT/UNSO vegetation map of Africa, UNESCO, Paris. 